\title{
OBITUARIES
}

\section{Ida Caroline Ward}

In the death of Professor Ida Ward in the Guildford Hospital on 10th October 1949, just after her sixty-ninth birthday, African studies lost one of their greatest exponents, and Africa one of its best friends.

Ida Caroline Ward was born in Bradford on the 4th October 1880, the eighth child of a Yorkshire wool merchant. From a school in Bradford she went to the Darlington Training College and later to Durham University, where she graduated B.Litt. with distinction. The North Country background of her early years remained with her always and gave a delightful "common-sense" colour to her character.

After sixteen years of teaching in secondary schools, she joined the Phonetics Department under Professor Daniel Jones in University College, London, in 1919 , and soon established herself as an authority in the phonetics of the main European languages and in the study of speech defects. Noteworthy works of this period are $A$ Handbook of English Intonation (written in collaboration with the late Lilian E. Armstrong), The Phonetics of English, and Speech Defects, Their Nature and Cure. Her interest in her mother tongue persisted, and she was actually working on another edition of the book on English Intonation when she died.

It was while lecturing at University College to missionaries that her interests turned towards West African languages-Kanuri, Igbo and Efik were her first fields of African research-and her first major work, The Phonetic and Tonal Structure of $E f i k$ (for which the University of London awarded her the D.Lit. in 1933), threw a new light on the study of these languages, and showed that intonation, that element hitherto so elusive, was one that could and should be studied if justice was to be done to African languages.

Dr. Ward's first visit to West Africa in 1933 was followed in 1936 by $A n$ Introduction to the Ibo Language, another major work. She also wrote many articles in journals, all of a hitherto unheard-of degree of accuracy.

Dr. Ward was a Foundation Member of the International Institute of African Languages and Cultures (later to become the International African Institute), and at once took an active part in its work, becoming a member of its Linguistic Group in 1931. She assisted in the preparation of the revised Practical Orthography of African Languages and translated it into English from Professor Westermann's German version. But the work which perhaps has had the greatest influence on African studies was Practical Phonetics for Students of African Languages (in conjunction with Professor Westermann, 1933, revised 1948). She also wrote $A$ Short Guide to the Recording of African Languages (Mem. xi, 1933), and Practical Suggestions for Learning an African Language in the Field (Mem. xiv, 1937).

In the meantime, the then School of Oriental Studies had launched a joint 
department of African Languages and Phonetics under Professor Lloyd James (1932), and Ida Ward was one of the original members. It was only natural that on the separation of the two branches of study in 1937 she should become Head of the new Department of the Languages and Cultures of Africa.

Financially the early days of the Department were precarious, and for several years both it and the International African Institute were dependent solely on a gradually dwindling grant from the Rockefeller Foundation. It was largely Dr. Ward's powers of persuasion which induced first lukewarm and then enthusiastic interest in the subject of African studies on the part of both the Colonial and Home Governments. With the alteration of the School's name to "School of Oriental and African Studies" in 1938 the Department felt its position secure for the first time.

From another point of view, too, the early days of the Department were unsettled. Dr. Ward and her limited staff were faced almost daily with demands for teaching or advice in languages about which little or nothing was known, so that intensive research had to go hand-in-hand with instruction. It was one of her jokes that in one particular language she and her African informant were never more than one lesson ahead of her eager student. It was fortunate that the phonetic tradition was well established in the Department from the beginning, or these manifold demands could never have been adequately met.

In 1936 Dr. Ward was appointed representative of the School on the Governing Body of the International African Institute, and in 1938 she and several of her staff became members of the Linguistic Advisory Committee to the Institute, she herself becoming Chairman to its successor, the war-time Interim Language and Literature Committee. In fact from 1939 onwards she virtually replaced Professor Westermann as adviser on all linguistic matters, and it was under her Chairmanship that the work on the forthcoming Handbook of African Languages was initiated.

In 1939, although verging on sixty years of age, Dr. Ward made her second expedition to West Africa (Nigeria and the Gold Coast), following up the orthographic trail blazed by Professor Westermann, and, with great daring, for the submarine war was in full swing, a more extensive tour in 1943-44. This was followed by her valuable book Gold Coast Languages (1945), which set out the orthographic problems as never before. By now her value as linguistic and goodwill envoy was apparent, and only those who have sat on African linguistic and orthographic committees can realize how heated the discussions may become.

In 1944 the University of London conferred on her the title of Professor of West African Languages.

The demand for African language teaching had fallen off during the early part of the war, but during the later stages and afterwards the Department was faced with new demands as the Government's Colonial Welfare and Development plans, the "Devonshire" Training Scheme for Colonial administrative service, and the "Scarbrough" scheme for post-graduate training of linguists came to fruition. Professor Ward met her greatest challenge when 
the School was asked to undertake the intensive training of some hundred Colonial Office " cadets" annually. With a strongly augmented staff, in which Africans and Europeans figured in about equal numbers, this task was faced, and after a year of intense work, during which eleven African language courses were worked out, and extensive gramophone records made, the scheme was launched in 1947, and was immediately popular.

In the New Year Honours List for 1948, the conferment of a C.B.E. provided ample evidence of the high esteem in which Professor Ward and her work were held. In the same year she made a tour in the United States to American learned societies, universities, etc., under a grant from the Rockefeller Foundation, and returned after having conquered another field. Professor Ward now retired from the Headship of the Department of Africa after two extensions beyond the normal age, and was immediately created Professor Emeritus, and stayed on as Adviser in African Studies. Relieved of the weight of administration, she threw herself with renewed vigour into the work she loved best. For in addition to "Scarbrough" and other students, Africans themselves were by now arriving in ever increasing numbers from the various Colonies, sent by their Governments to study their own mother tongue scientifically. This was indeed work after her own heart, and her African students will always remember the courses she gave them.

The new and obvious step was the creation of African Departments in Africa itself, and she was in the midst of preparations for yet another expedition at the request of the Gold Coast University when her illness overtook her. She had achieved her aim to put African studies on the map, however, and it would have delighted her to know that African languages will now be studied at the Gold Coast University (Achimota), at Ibadan (Nigeria) and at Makerere (Uganda).

The outstanding qualities of Ida Ward's character were her kindness and sympathetic understanding. She always put both staff and students at their ease, and the African members of the School found in her an understanding " ma" to whom to take their problems. The outside world, whether governmental, mission or lay, found her equally approachable. "It is not an exaggeration to say," was one comment, " that no secretary of a mission society appealed to her in vain for the linguistic help needed by any missionary or group of missionaries," and this may truthfully be said of all who came to her for advice. But those of us who knew "Wardie" intimately will also remember with affection the little white-haired lady, living happily with her widowed sister in Golders Green, proud of her small garden and immensely proud of her great-nephew and niece. For her home life was as vivid as her academic life.

A. N. TUCKER.

At the Memorial Service to Professor Ward in the Woburn Square Church on 26th October, the Director of the School gave the following address :- 
We are met here to commemorate and to affirm our gratitude for the life of a great and good woman, Dr. Ida Ward, Professor Emeritus of West African languages in this University and sometime Head of, and creator of, the African Department in the School of Oriental and African Studies.

Throughout the world wherever and whenever the study of African languages is reviewed, it will be for ever associated with the name of Ida Ward. It was as a member of the Phonetics Department of University College that she first turned her attention to the study of an African language. Then, in 1932, she joined the staff of the School of Oriental Studies. This move was not only a great good fortune for our School ; it was also the prelude to sixteen years of untiring and selfless work in the field she had now taken as her own. They were years in which she made great personal contributions to the knowledge and understanding of the languages of West Africa and to the solution of many problems connected with their emergence as vehicles of education, literature, and administration.

Still more were they years during which, as head of the Department, she inspired all her fellow-workers in the field of African linguistics with her own enthusiasm and her devotion to the pursuit of knowledge, her own love for the peoples of Africa and her deep and abiding concern for their welfare. His Majesty's Secretary of State for the Colonies in a letter written after her death says: "I am deeply conscious of the immense amount of time and work Professor Ward devoted to the interests of Colonial peoples." That is a true word. All Africans, whether fellow citizens in the Commonwealth or not, who came into contact with her, in the School, in the International Institute, or on her visits to African countries, regarded her with a warm and true affection, for they recognized in her one who deeply loved their peoples.

Let those who loved her find joy and comfort in the knowledge that these were years of much happiness to Ida Ward. On the last occasion on which we talked together, when already she knew what lay ahead, she said: "Whatever comes, I can have no complaint: I have had a full and happy life."

For us who were her colleagues and friends the name of Ida Ward will for always stand for kindness, courage, a robust North Country humour and common sense, and self-sacrificing work for a great ideal. In sixteen years of close association I never heard her utter an unkind word or ascribe to another an unworthy motive. We mourn the loss of a dear friend; but throughout our lives the memory of her goodness will be an enduring possession. For goodness was her essential quality.

"In the memory of virtue is immortality, because it is recognized both before God and before men ; when it is present men imitate it, and they long after it when it is departed; and throughout all time it marcheth crowned in triumph, victorious in the strife for the prizes that are undefiled."

A committee of the African members of the School has also drawn up an address in memory of Professor Ward. This here appears in one of their own 
languages-Yoruba, the language on which she was working when she died :-

\section{ERIN WÓ!}

Iya Ãfin, Dr. Ida C. Ward, re 'lé.

K'a to r' erin, o d'igbó, k'a to r'ệọ̀n o d'ọdàn, k'a to r'ẹiyẹ bi ọ̣kín, o di kese. K’a to ri aláwọ funfun ti yio șe bi Dr. Ward olõgbé, ọna yio jìn!

Ninu gbogbo awọn ogbogi ninu iwe ti a npe ni Professor ni Ile Ekko giga, ti a gbe nkọ orișiriși ede ilẹ enia dudu ati ede apa Ila Orun ni " University of London", ọkan pataki ni Dr. Ida C. Ward, C.B.E., D.Lit., ẹniti o șe alaisi ni ojọ kẹwa oṣu October ni ọdun 1949, jẹ.

Iku Iya oninũre yi dun awa enia dudu ti a nkẹko ati awa ti a nșisẹ ni ile ẹkọ giga yi. $O$ ni ìdí ti ọran nã fi dùn wa wọra bệ. Li ọna kini, Dr. Ward mọ aýnike orișiriși ede awa enia dudu dé góngó. $\mathrm{O}$ mọ àpadé àludé ede wa ju awa elédè pãpã lọ. Olọrun li o fi iṣẹ nã rán a. Nigba aiye rẹ̀, o si nfi ẹ̣kọ ede nã kọ awọn ọmọ ilẹ enia dudu li oju mejẽji. Gbogbo ojọ aiye rẹ̀ li o fi da ara dé iṣe nla yi. $O$ ti rin irin àjò lọ si ile wa. $O$ ti kọ orișiriși iwe pataki-pataki lori èdè wa. Ẹnu iwe nlá-nlà ti o nkọ lori ede Yoruba ni Dr. Ward wà ti titan fi dé. Adura wa ni pe ki nwọn lè tẹ iwe yi ki o le jade laipe fun lilo gbogbo awọn ọmọ Yoruba ati awọn ẹlomiran ti nwọn fẹ kọ ede Yoruba. Laișe àní-àní irohin kò tó afojuba, ni iwe nã yio jẹ: kò si meji ejò ni!

Ohun ti o tile wa jẹki iku Dr. Ward dá otutu sile si gbogbo wa lara ni inurere ati ifẹ ti iya nã fi mba gbogbo awa enia dudu abẹ rẹ lò. Gẹgẹ bi iya iti iṣe fun awọn ọmọ rẹ̀ ni Dr. Ward nṣe fun gbogbo wa. Kò mọ dudu yàtọ si funfun. O șe, enia 're lọ!

Kiní kanșoșo li o kù ti a lè șe. Bi a ti ngbadura pe ki Edumare fi ibukun rẹ sori iṣe nla ti Dr. Ward da sile ki o to fi aiye silẹ, ki awa nã șe apa kítípó, ki a mã ba iṣe ti o fi silẹ lọ. Iba ệkọ ti a kọ́ labẹ Dr. Ward, ki awa nã fi le awọn ọmọ iya wa lọwọ. Ki ẹ̀kọ ijinlẹ li ede awa enia dudu lè mã lọ siwaju ati siwaju lãrin wa.

Ki Ọlọrun ki o dẹlẹ fun iya oninũre yi, ki o fi ọ̀run kẹ ẹ, ki o si busi iṣẹ ti o dá silẹ ki o to șe alaisi.

To those words it has seemed fitting to add by recalling the messages of appreciation and farewell addressed by African members of the School to Professor Ward on the occasion of her retirement. In fourteen languages the speakers voiced their gratitude for Professor Ward's work and friendship and their hopes for the fulfilment of the tasks on which she was still engaged :-

(Bemba.) Tuamuposia mukuayi, ciaciine imue muli nnakulu kuabalubuluile indimi siafuebaafiita.

(Efk.) Abasi odion fi, onyuy ekpeme fi ono nnyin. Sosogo, ke nti utom fo.

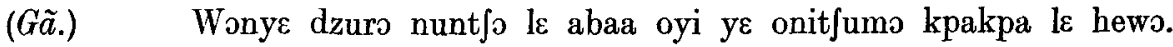
Oyaba dzobgang.

(Ganda.) Akola obulungi yeebazibwa ; weebale Mukyala Ward, era weeraba. 
(Hausa.) Muna yi miki fatar ki huta lafiya a cikin salama. Allah shi kara miki lafiya, shi ba ki yawancin rai da kyakkyawan karko. Amin !

(Ibibio.) Imukoom eti eti ke nti utom mfo.

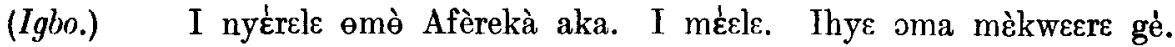
Dèkwa ndhè ogologo.

(Mende.) Mu gohu neni kia bi lima. Gbamaile bi hinda nyandengo. Dgewo i bi luba ka!

(Nyanja.) Muluygu akudaliseni nakupasani mtendele masiku onse.

(Sotho.) U e loanne. Mesebetsi ea hao e tla u paka le melokong e tlang.

(Swahili.) Tunakuombea Mungu akuzidishie heri na baraka milele.

(Twi.) Obaapanin, yene wo nni aseda.

Ade $\varepsilon$ kye a, yeda wo ase. Kosekose.

Enowaa baapanin,

Yema wo mo-ne-yo

Ade $\varepsilon$ kye a, wo mma da wo ase.

Yeda wo ase ahenewa!

(Xhosa.) Inkosi mayife nawe.

(Yoruba.) Ẹ ku ișẹ, ẹ ku ori 're, atubọtan yio dara o!

\section{Mirzā Muhammad Khān Qazvīnī.}

The death of Mìrzā Muhammad Khān Qazvinī is a great loss to scholarship, and will be felt most keenly in Persia itself, where men of such learning are rare to-day. I do not propose to say much here about the details of his life, for in 1924 he wrote a fairly full autobiography, which was published with four other lives as an appendix to The Bulletin of the Sciences of Finance and Economics, Tehran. This autobiography was reprinted in a collection of his articles called Bīst Maqāleh e Qazvīn̄̄ Vol. I (ed. Poure-Davoud, Bombay, 1928). More recently he wrote a shorter account of his life, which was published in the monthly periodical Yaghma (Mibr 1327/Sept. 1948). He died on 27th May 1949, when he was 72 years old, having been born in March 1877/Rabi' I 1294. A moving obituary by his great fellow-scholar, S. H. Taqizädeh, appeared in the Ittila $\bar{a}^{\zeta} a \bar{t}$, and The Times of London published an obituary notice a week later.

Qazvini's father was a scholar of some repute, and one of the four jointauthors of the great Persian biographical work Nämeh-e Däneshvarän. Qazvini himself, who was born in Tehran, was educated under the traditional Eastern system, and learnt more by his own efforts than from formal instruction. He was orphaned before he was twelve, and soon afterwards became a student (talaba) in one of the old religious colleges supported by charitable bequests; but like other zealous students he managed to attend the lectures of all the eminent masters of his time. He studied șarf, nahı, adab, fiqh, kaläm, hikmat, 